\title{
International
}

\section{APSA Africa Workshop: Ouagadougou, Burkina Faso}

\section{"Religion and Politics in Comparative Perspective"}

\author{
Andrew Stinson, Coordinator, International Workshops, APSA
}

$\mathrm{T}$ he sixth annual APSA Africa Workshop was conducted in partnership with the Institute for Governance and Development (IGD) in Ouagadougou, Burkina Faso, from July 1 to 12 . The event is part of a multiyear initiative to support political science research and teaching in Sub-Saharan Africa through a series of residential political science workshops at African universities and research institutions. Funded by the Andrew W. Mellon Foundation, the Africa Workshops program is a major component of APSA's efforts to engage with political science communities outside the United States and support research networks linking US scholars with their colleagues overseas.

The 2013 workshop, "Religion and Politics in Comparative Perspective," focused substantively on the distinct roles of religion in the Anglophone and Francophone state traditions, the potential differences of political culture within Christianity and Islam (the two major religions of contemporary Africa), and the current national debate in Burkina Faso over laïcīté (secularism). A team of five senior scholars from the United States and Africa co-led the event, which was attended by 27 political and social scientists. The participants, who included 22 Africa-based scholars and five advanced $\mathrm{PhD}$ candidates from the United States and Europe, were competitively selected from a pool of more than 130 applicants. The 2013 workshop was conducted as a bilingual workshop and was evenly composed of both Anglophone and Francophone scholars. Together, they represented 26 different institutions from 19 countries and comprised the largest and one of the most diverse groups to date.

Throughout the workshop, participants drew on an extensive set of readings

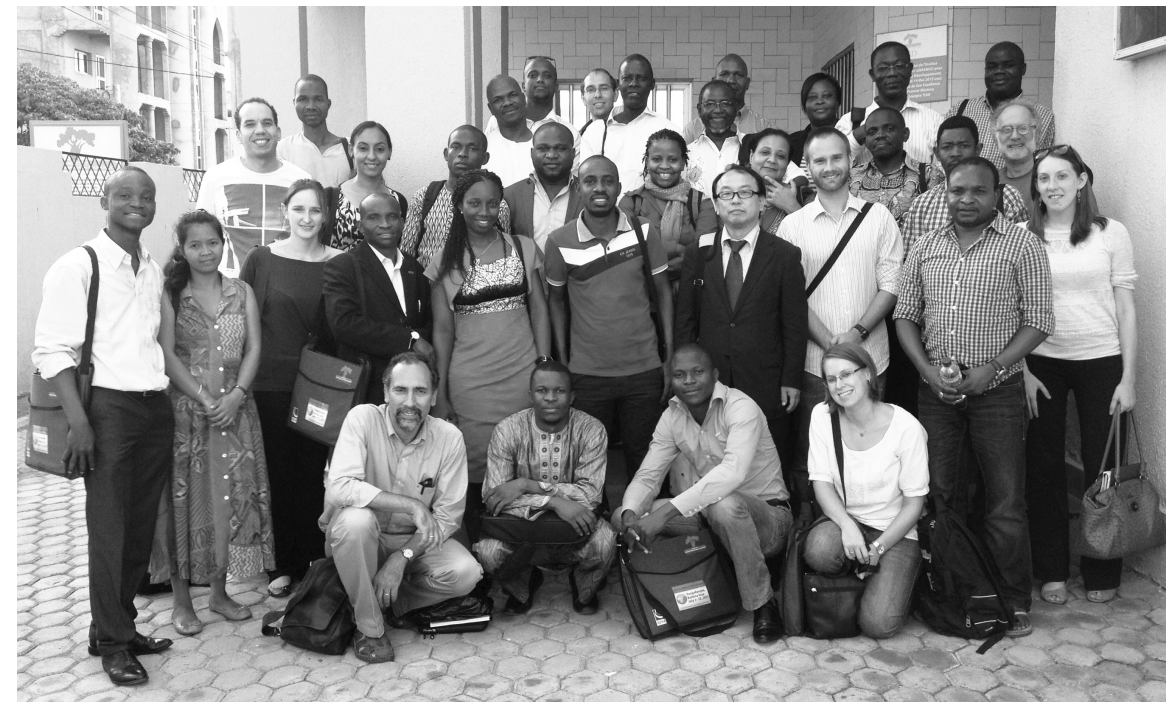

2013 participants and co-leaders pose with former Japanese ambassador to Burkina Faso, Yuku Murata, who gave a guest lecture on religion and politics as it relates to Japan. Front Row: Leonardo Villalón, Mamadou Dembele, Béranger Avohouémè, Shirley De Villiers. Second Row: Léon Sampana, Baholy Malala Ravonison, Melina Izama, Moses Aluaigba, Onyima Blessing Nonye, Issouf Binaté, Yuku Murata, Daniel Eizenga, Hassan Ndzovu, Catherina Kelly. Third Row: Salim Hmimnat, Mai Azzam, Luqman Saka, Doris Ehazouambela, Aikande Kwayu, Einas Ahmed, Willy Kalala Kankonde, Edmond VII Mballa Elanga, Kenneth Wald. Back Rows: Yacouba Ouédraogo, Nasir Baba, Mouhoumed Abdoulkader Hassan, Jason Klocek, Taiwo Owoeye, Mahaman Tidjani Alou, Karim Saidou, Tapiwa Mapuranga, Augustin Loada, Boniface Dulani.

as well as their own research to discuss conceptual and methodological issues in the study of religion and politics. These issues were also explored through meetings with the Archbishop of the Roman Catholic Church in Ouagadougou, the president of the National Muslim Students Association, and the local King of the Mossi people, the Moro Naba. A spirited public panel discussion at the University of Ouagadougou further sensitized participants to the complexity of religious issues in the host country. Participants also made time to experience Burkina's rich culture of the arts through visits to a granite sculpture garden and Opera Village near Laongo and an evening film screening from the 2013 Pan African Film and Television Festival of Ouagadougou.
A special word of thanks is due to Abdoul Karim Saidou, Program Coordinator at IGD and Chief of Services and Operations at the Center for Governance

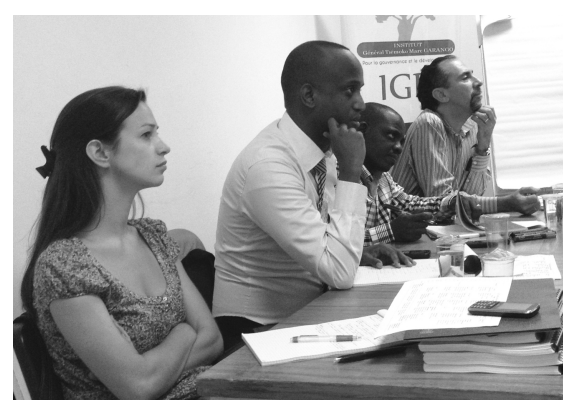

Workshop participants Adrienne Vanvyve (Belgium), Mouhoumed Abdoulkader Hassan (Djibouti), Willy Kalala Kankonde (D.R. Congo), and co-leader Leonardo Villalón (USA) listen to a plenary discussion at IGD. 


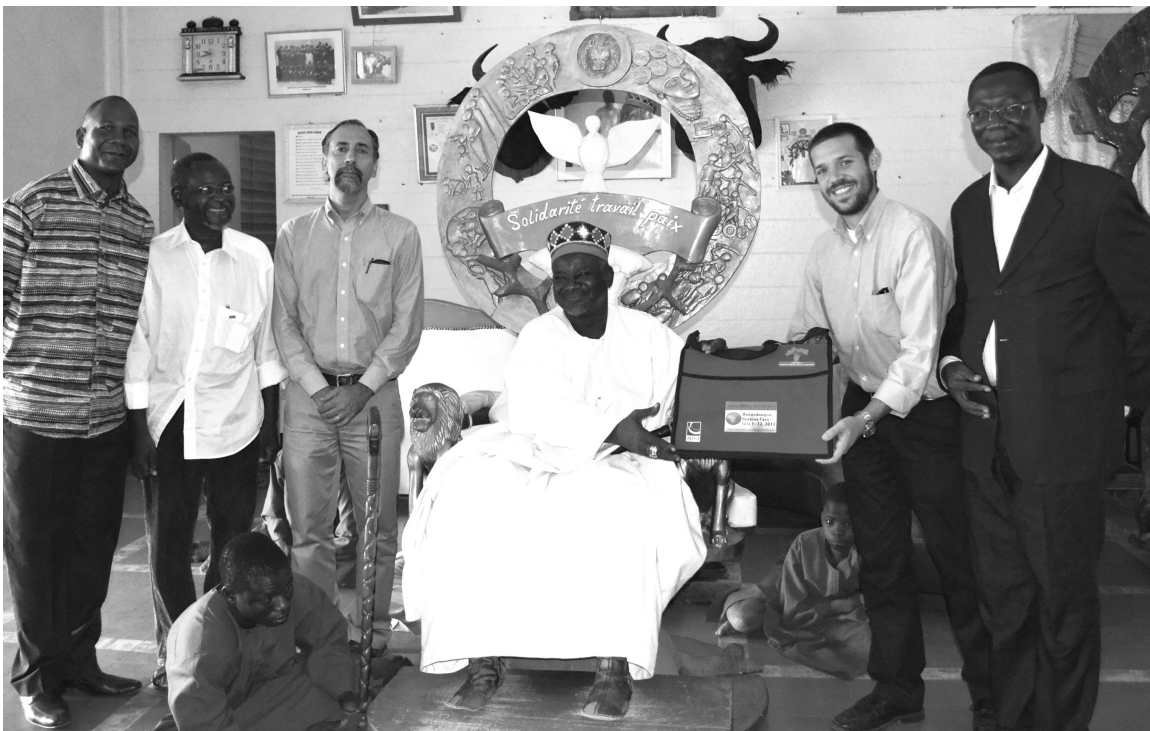

On the final day of the conference, we visited with the Moro Naba, traditional king of the Mossi people, to learn his views on laïcité, religion and the state in Burkina Faso. APSA staff member Andrew Stinson presents the Moro Naba with a small gift alongside several of the workshop leaders.

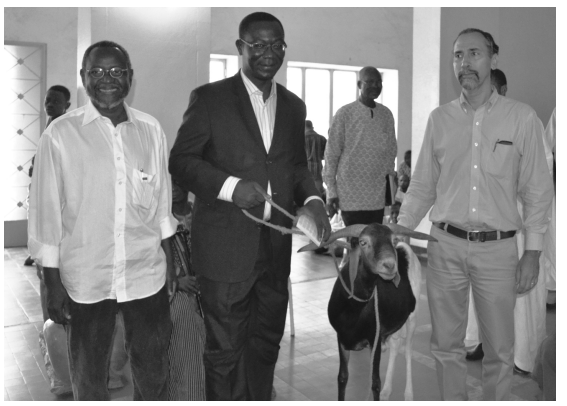

Workshop co-leaders Mahaman Tidjani Alou (Niger), Augustin Loada (Burkina Faso), and Leonardo Villalón (USA) pose with a ram that was given to the APSA delegation by the Moro Naba.

Photo credit: Photographs courtesy of Andrew Stinson.

and Democracy in Ouagadougou, who provided invaluable assistance in facilitating the workshop. Karim is also an alumnus of the 2009 Africa Workshop in Ghana.

The event has now been held three times in West Africa (Burkina Faso, Ghana, and Senegal), twice in East Africa (Kenya, Tanzania), and once in Southern Africa (Botswana). To date, 120 Africabased scholars from 31 countries have
Ms. Mai Azzam, University of Khartoum; Sudan

Mr. Nasir Baba, Usmanu Danfodiyo University; Nigeria

Mr. Issouf Binaté, Université Alassane O. de Bouaké; Côte d'Ivoire

Ms. Onyima Blessing Nonye, Nnamdi Azikiwe University Awka; Nigeria

Mr. Mamadou Dembele, Université des Sciences Juridiques et Politiques de Bamako; Mali

Mr. Boniface Dulani, University of Malawi; Malawi

Mr. Doris Ehazouambela, Ecole des Hautes Études en Sciences Sociales; France

Mr. Daniel Eizenga, University of Florida; USA

Mr. Salim Hmimnat, Institut des Etudes Africaines à l'Université Mohammed V; Morocco

Ms. Melina Izama, Stanford University; USA

Mr. Willy Kalala Kankonde, Université de Kinshasa; D.R. Congo

Ms. Catherina Kelly, Harvard University; USA

Mr. Jason Klocek, University of California, Berkeley; USA

Ms. Aikande Kwayu, BUMACO Ltd; Tanzania

Ms. Tapiwa Priase Mapuranga, University of Zimbabwe; Zimbabwe

Mr. Edmond VII Mballa Elanga, University of Yaoundé I; Cameroon

Mr. Hassan Ndzovu, Freie University Berlin; Germany

Mr. Yacouba Ouédraogo, Université de Ouagadougou; Burkina Faso

Mr. Taiwo Owoeye, Ekiti State University; Nigeria

Ms. Baholy Malala Ravonison, Université d'Antananarivo; Madagascar

Mr. Luqman Saka, University of Ilorin; Nigeria

Mr. Léon Sampana, Université Ouagadougou II; Burkina Faso

Ms. Adrienne Vanvyve, Université Libre de Bruxelles; Belgium

Ms. Shirley De Villiers, University of Pretoria; South Africa 